\title{
Medical Management of Growth Hormone-Secreting Pituitary Adenomas
}

\author{
Michael S. Racine and Ariel L. Barkan \\ Division of Endocrinology and Metabolism, University of \\ Michigan Medical Center, 3920 Taubman Center, Box 0354, \\ Ann Arbor, Michigan 48109-0354, USA
}

\begin{abstract}
The primary treatment of acromegaly remains transsphenoidal adenomectomy, yet the tissue overgrowth of acromegaly often progresses following surgery, and responds to radiotherapy only after significant delay. Persistently elevated serum growth hormone (GH) and insulin-like growth factor-I (IGF-I) concentrations can be normalized in about half of post-surgery acromegalics using the pharmacologic alternatives presently available, the dopamine agonists (DA) and somatostatin (SST) analogs. Cabergoline, the most efficacious DA, normalizes IGF-I in approximately $37 \%$ of patients, whereas the long-acting SST analogs, Octreotide LAR and Lanreotide SR, do so in $66 \%$. Significant tumor shrinkage may be attained with SST analogs in particular, and when necessary, the primary medical treatment of acromegaly may be successfully addressed with this class of drugs. Greatly enhanced efficacy is expected from the GH receptor antagonist pegvisomant, which is nearing market availability and will enable the normalization of serum IGF-I in virtually all patients treated. We review here the pharmacologic treatments of excessive GH secretion.
\end{abstract}

Key Words. pituitary adenoma, acromegaly, dopamine agonist, somatostatin analog, pegvisomant

\section{Introduction}

Acromegaly, a syndrome of tissue overgrowth that results from high concentrations of circulating insulinlike growth factor I (IGF-I) is, in the vast majority of cases, a consequence of the hypersecretion of growth hormone $(\mathrm{GH})$ from a benign monoclonal adenoma of pituitary somatotropes [1]. GH-secreting adenomas account for about 10 percent of all pituitary tumors that come to medical attention $[2,3]$. Though the disease is uncommon, with an estimated prevalence of 40 to 50 per million population, it is believed to be widely underdiagnosed due to its insidious nature and a general low level of disease awareness in the medical community. As a result, despite the well-described features of the syndrome, patients often live with active disease for up to 10 years before a diagnosis is made [4]. When suspected on clinical grounds, the diagnosis of acromegaly is relatively straightforward and is confirmed by elevated age- and sex-adjusted serum IGF-I with GH that fails to suppress to less than $1 \mathrm{ng} / \mathrm{mL}$ after oral glucose challenge. The common co-morbidities of diabetes mellitus, hypertrophic cardiomyopathy, hypertension and hypopituitarism decrease the life expectancy of patients with acromegaly by an average of 10 years [5]. Cancer-related mortality is increased, as reported by Orme et al. [6] in a series of 1362 patients with acromegaly, particularly in patients with colon cancer and in those with post-treatment GH levels above $2.5 \mathrm{ng} / \mathrm{mL}$. The overall incidence of cancer does not appear to be affected [6].

Surgical excision via transsphenoidal approach remains the preferred primary treatment of GH-secreting adenomas. Ongoing postoperative surveillance is necessary, as the strict normalization of circulating GH and IGF-I requires aggressive secondary treatment in greater than half of patients. Surgeons with extensive experience in excising $\mathrm{GH}$-secreting microadenomas $(<10 \mathrm{~mm}$ in diameter) report cure rates between 60 and 90 percent [7-10] though this success rate represents the very best outcome, and is not likely matched by surgeons with less experience in pituitary microsurgery. Moreover, fewer than one third of GH-secreting tumors are less than $10 \mathrm{~mm}$ in diameter at diagnosis, and GH secretion from a macroadenoma is normalized by surgery alone in less than half of cases [7-10].

Adjunctive treatment in the form of fractionated external beam radiotherapy, typically 40-50 Gy delivered over a 5-6 week period, is commonly used, although the benefits of radiotherapy can be offset by serious complications including the onset of hypopituitarism which occurs in 30 to 70 percent of patients in the decade after treatment [11-13]. The delay between radiation treatment and normalization of GH secretion, which can range from 5 to 10 years, means patients continue to face active acromegaly for considerable time after treatment, necessitating the use of adjunctive medical treatment. Finally, the reported rates of normalization of IGF-I following radiotherapy are widely disparate, from 5 to about 70 percent [13-16], and other risks such as vascular damage and secondary neoplasms, though rare, should be weighed against the potential benefits. Stereotactic radiosurgery employing gamma knife, proton beam, or LINAC, may decrease these

Address correspondence to: Michael S. Racine, Division of Endocrinology and Metabolism, University of Michigan Medical Center, 3920 Taubman Center, Box 0354, Ann Arbor, Michigan 48109-0354, USA. Tel: (734) 936-8279; Fax: (734) 936-9240. 
adverse effects [17-19] but is available in relatively few centers.

The prospect of effective management of acromegaly through medical treatment has come within reach of increasingly more patients since the introduction of dopamine agonist therapy for GH-suppression in the 1970's. Presently, the long-acting analogs of somatostatin offer the best efficacy of the GH-suppressive agents; IGF-I may be normalized in up to two thirds of postoperative acromegaly patients treated with octreotide LAR. We review here the two modalities of medical treatment of acromegaly relied upon most in the past three decades-dopamine agonists, with particular attention to cabergoline, and somatostatin analogs, with emphasis on the long-acting formulations. Lastly, early reports of the clinical efficacy of the forthcoming $\mathrm{GH}$ receptor antagonist, pegvisomant, are reviewed.

\section{Background}

Several clinical goals must be addressed by any strategy for the treatment of acromegaly, including the relief of symptoms of tissue overgrowth, the alleviation of tumor mass effects while preserving or restoring normal pituitary function, the normalization of circulating IGF-I, and, ultimately, the normalization of mortality. Though GH secretion may remain elevated, some mitigation of symptoms, particularly of arthralgias, can occur with any significant decrease in IGF-I levels [20]. In the assessment of surgical outcome, the lowest random or fasting serum GH level achieved postoperatively has generally been accepted as an indicator of biochemical status. Normalization of the mortality rate associated with acromegaly has been demonstrated when random GH levels of less than $2.5 \mathrm{ng} / \mathrm{mL}$ [4,21], and even of less than $5 \mathrm{ng} / \mathrm{mL}$ are reached $[9,22]$, though these levels do not necessarily indicate normalized GH secretion. While the definition of normal GH secretory dynamics has become increasingly rigorous, the biochemical definition of 'cured' acromegaly has concurrently become less certain. Newer, more sensitive assays for GH and IGF-I have enabled the detection of persistently, albeit mildly, abnormal GH secretion following surgery, making the question of what constitutes normalized GH secretion debatable [23-25]. Postoperative GH secretion may remain abnormal in many patients when assessed by oral glucose suppression and employing a sensitive GH assay [26,27]. Still, a window of 'safe' GH secretion may be identified. Based on an analysis of the GH responses to an oral glucose tolerance test (OGTT) in 32 patients with treated acromegaly compared with those in 56 normal control subjects, Costa et al. [27] advocated the criterion of glucose-suppressed GH to under $1 \mathrm{ng} / \mathrm{mL}$ as indicative of safe GH secretion, a conclusion which supported previously published recommendations [28].

Growth hormone dynamics alone must not be relied upon to accurately represent disease status, however. Serum IGF-I has emerged as a more reliable biochemical marker of GH effect at the tissue level [26-31]. Though the circulating concentration of serum IGF-I is affected by nutritional state, hepatic function, age, and gender, in addition to the GH secretory status, it is a very reliable reflection of overall 24-hour GH-tissue effect. When measured using a well-validated assay with age- and sexspecific normative data, IGF-I is the best and most costefficient marker for assessing the adequacy of treatment of acromegaly, and should be the preferred marker for assessing biochemical cure.

The lowering of IGF-I has been associated with reductions in acromegaly-related mortality [26] yet questions surrounding the GH/IGF-I relationship remain to be answered, as normalization of IGF-I may still be accompanied by persistently abnormal secretory GH dynamics [26,27]. Conversely, abnormal GH secretion as assessed by OGTT suppression or mean 24-hour GH, applying currently accepted norms, may not always correlate with the finding of elevated IGF-I, as recently shown by Dimaraki et al. [32]. In this study, 16 patients with clinical features of acromegaly and serum IGF-I levels that were elevated for age- and sex-matched controls, had mean 24-hour GH levels less than $2.5 \mathrm{ng} / \mathrm{mL}$, within the previously accepted normal range for healthy adults. Eight patients also had glucose-suppressed GH levels under $1 \mathrm{ng} / \mathrm{mL}$, yet GH-producing pituitary adenomas were identified histologically in surgical specimens from 13 of 14 patients. These findings show that IGF-I and GH results can be discrepant, and cast further doubt on the merit of using dynamic GH testing alone in the diagnosis or follow-up of acromegaly. The measurement of serum IGF-I in a sensitive assay with established ageand sex-adjusted normal ranges is of chief importance in the assessment of surgical or medical treatment.

\section{Dopamine Agonists}

Although dopamine agonists are considerably less effective in decreasing GH hypersecretion in acromegaly than they are in subduing hyperprolactinemia, cabergoline is frequently useful in the treatment of acromegaly with concomitant prolactin hypersecretion, and is a valid agent in the medical treatment of GH hypersecretion. Up to $40 \%$ of GH-secreting adenomas co-secrete prolactin [33], and dopaminergic $\mathrm{D}_{2}$ receptors are expressed by some somatotropes [34,35]. Dopamine is a catecholamine neurotransmitter with diverse functions, including the regulation of some neuroendocrine systems. Dopamine restrains prolactin secretion and stimulates GH release in healthy subjects, though it paradoxically suppresses GH release in some patients with acromegaly [36,37]. The dopamine agonists currently available in the United States, bromocriptine, pergolide, and cabergoline, are synthetic derivatives of ergot alkaloids originating in the fungus Claviceps sp. [38], and have been used in the treatment of acromegaly since bromocriptine was first introduced in the mid-1970s [39]. 
In acromegaly, as 24-hour GH secretion increases, serum IGF-I levels show a parallel rise until a GH concentration of $10-20 \mathrm{ng} / \mathrm{mL}$ is reached, at which point IGF-I concentrations plateau [30]. Therefore, though serum GH concentrations may fall significantly under the inhibition of a dopamine agonist or other medication, IGF-I levels are unimproved if the mean GH concentration remains above $10-20 \mathrm{ng} / \mathrm{mL}$. In light of this, many of the early efficacy studies of bromocriptine in acromegaly are difficult to interpret as they assessed outcome based on percent suppression of GH from baseline levels. A 1994 review of 31 published studies of bromocriptine involving a total of 549 patients with acromegaly and using daily doses of 5 to $80 \mathrm{mg}$ demonstrated an overall success rate (defined as suppression of $\mathrm{GH}$ to less than $5 \mathrm{ng} / \mathrm{mL}$ ) of $20 \%$, while IGF-I was normalized in a mere $10 \%$ of patients [38].

There are few published studies of pergolide for the treatment of acromegaly. A review of the medical literature published in English yields two small studies involving a total of 15 patients with acromegaly treated with daily doses of pergolide of 100 to $1500 \mathrm{mcg}$ orally, over 4 to 31 months. Combining these studies, pergolide suppressed GH to an average of $50 \%$ of baseline, while just $27 \%$ (4 of 15) patients reached a serum GH less than $5 \mathrm{ng} / \mathrm{mL}[40,41]$. In these studies, IGF-I normalization was not reported.

Cabergoline (Dostinex ${ }^{\circledR}$, Pharmacia Corp., Peapack, New Jersey, USA) is a dopamine agonist with more specific $\mathrm{D}_{2}$ receptor binding capacity than bromocriptine, and is currently the best of this class of drugs for the treatment of both prolactin- and GH-secreting pituitary adenomas. The serum half-life of cabergoline is about 65 hours, allowing oral administration just once or twice per week [42], which, with its better tolerability in comparison with bromocriptine, enhances patient compliance. In the first multicenter trial of cabergoline in acromegaly, Abs et al. administered cabergoline to 64 patients and followed them from 3 to 40 months [43]. Cabergoline was initiated at a dose of $0.5 \mathrm{mg}$ twice weekly. By study end, the weekly dose was $1.75 \mathrm{mg}$ ( $0.5 \mathrm{mg}$ every two days) or less in $87 \%$ of patients. Serum IGF-I was lowered to less than $300 \mathrm{ng} / \mathrm{mL}$ in $50 \%(8 / 16)$ of patients with prolactin co-secretion, and in 35\% (17/48) of patients without concomitant hyperprolactinemia. Patients with a pre-treatment serum IGF-I under $750 \mathrm{ng} / \mathrm{mL}$ showed the most vigorous response. Random serum GH was lowered to less than $5 \mathrm{ng} / \mathrm{mL}$ in $73 \%$ of patients, and to less than $2 \mathrm{ng} / \mathrm{mL}$ in $46 \%$. Cozzi et al. [44] reported the effect of cabergoline in a smaller study of 18 acromegaly patients over 6 months of treatment. Serum IGF-I levels were normalized in 5 of 18 patients, while mean IGF-I decreased from $720 \mathrm{ng} / \mathrm{mL}$ to $375 \mathrm{ng} / \mathrm{mL}$. Mean basal GH decreased from $6.6 \mathrm{ng} / \mathrm{mL}$ before treatment to $3.5 \mathrm{ng} / \mathrm{mL}$ afterwards. Combining these two studies, serum IGF-I was normalized in $36.6 \%$ (30/82) of patients, and pituitary adenoma size was reduced in $66.7 \%$ (16/24). Cabergoline is generally well tolerated $[43,44]$.
Though the treatment of acromegaly is an unapproved use of this drug, cabergoline has succeeded in renewing interest in the GH-suppressive treatment of acromegaly via activation of dopamine $\mathrm{D}_{2}$ receptors. Cabergoline offers the best efficacy of the dopamine agonists in the medical treatment of acromegaly, inducing a normalized serum IGF-I in approximately one third of patients, and in a higher percentage of those with prolactin co-secretion. In light of its superior side effect profile in comparison with bromocriptine and its lower cost in comparison with the somatostatin analogs, cabergoline is a legitimate first choice for adjuvant postoperative treatment of persistent GH hypersecretion, particularly in the patient with concurrent hyperprolactinemia.

\section{Somatostatin Analogs}

The somatostatin (SST) peptides are cyclic proteins 14 and 28 amino acids in length, which act on a diverse array of tissues in regulatory and suppressive functions. Cells that produce SST are scattered throughout the peripheral and central nervous systems, the gastrointestinal tract, and the immune system. Among the endocrine functions of SST are the suppression of insulin and glucagon secretion in the pancreatic islets, and the suppression of TSH and GH in the anterior pituitary [45-47]. Somatostatin-14 was first discovered in rat hypothalamus as an inhibitor of GH secretion [48]; its amino-terminal extended congener, SST-28 was described several years later [49]. The multiple functions of somatostatin and its ubiquitous distribution is dependent on an array of heterogeneous cell-surface receptors, and on their unique patterns of tissue expression. Five G-protein coupled, transmembrane somatostatin receptor (SSTR) isoforms were identified and characterized in the 1990's [50-52], all of which feature the familiar design of 7 cell membrane-spanning domains. Intracellular post-receptor effects occur through inhibition of intracellular $[\mathrm{cAMP}]$ and $\left[\mathrm{Ca}^{2+}\right]$ via functional connection between the receptor and adenylate cyclase, and cell-surface potassium and calcium ion channels, respectively [47]. Receptor subtypes 2 and 5 (SSTR-2 \& SSTR-5) are the predominate receptors found on the surface of pituitary somatotropes. Somatotrope adenomas may express SST receptors in higher density than surrounding normal pituitary [53], and the ratio of SSTR2/SSTR5 mRNA transcripts among GH-producing adenomas is highly variable [54]. Some tumors express neither receptor subtype [55], or express mutant SST receptors [56], and are thereby resistant to treatment with SST analogues.

The potential utility of a pharmacologic agent with somatostatin-like activity in the treatment of acromegaly is readily apparent. The half-life of native somatostatin in serum is less than 3 minutes, a property that would necessitate its delivery by constant infusion to achieve lasting, significant suppression of GH. Furthermore, its rapid decline in serum is followed by 
rebound hypersecretion of GH, insulin, and glucagon [57]. Therefore, the need for a more enduring synthetic ligand able to bind and activate SSTR-2 and SSTR-5 without rebound effects was evident to early researchers.

The development of the synthetic somatostatin analogs-octreotide and lanreotide-has overcome the pharmacokinetic challenges of native somatostatin. Both compounds are octapeptide molecules with binding affinity directed towards SSTR-2. The GHsuppressive effectiveness of octreotide is 45 times that of native somatostatin-14 [58], and its serum half-life after s.c. injection is about 100 minutes. Octreotide is usually given in three daily s.c. injections, in total daily doses of 300-750 mcg, though up to $1500 \mathrm{mcg}$ per day is sometimes necessary. GH secretion is rapidly suppressed after a single s.c. injection of octreotide, with a maximal effect between 2 and 6 hours after injection [59].

Early studies of octreotide therapy in small numbers of acromegaly patients were promising [60-63], and in a multicenter trial of s.c. octreotide in 189 patients followed from one to 33 weeks, serum GH was reduced to under $5 \mathrm{ng} / \mathrm{mL}$ in $45 \%$ [64]. In an attempt to differentiate nonresponders from those patients who will ultimately benefit from prolonged octreotide treatment, GH response to acute testing with $100 \mathrm{mcg}$ s.c. octreotide has been used [65], but has been shown to be of less value in predicting responsiveness than either one month of octreotide treatment or pre-treatment ${ }^{111}$ In-pentreotide scintigraphy for evaluation of the presence of tumor SSTR expression [66].

As a thrice-daily subcutaneous injection, octreotide poses the potential problem of noncompliance; the encapsulation of octreotide and lanreotide within slowly dissolving biodegradable polymer microspherules has provided for greater ease of compliance by allowing drug delivery by intramuscular depot injections. Within one hour after a single i.m. injection of long-acting release (LAR) octreotide (Sandostatin ${ }^{\circledR}$ LAR ${ }^{\circledR}$, Novartis Pharmaceuticals, East Hanover, New Jersey, USA), serum octreotide levels show a brief rise as the drug coating the surface of the microspherules enters the circulation. After a rapid fall, the serum concentration then rises again between 7 and 14 days after injection, and remains at a plateau for another approximately 19 days, before gradually tapering off [67]. The duration of effect, but not the potency of GH-suppression, is augmented by increasing doses. Monthly (every 4 weeks) i.m. injections allows for octreotide levels sufficient for constant GH-suppression to be maintained [68], although adequate control may also be maintained on a q 6 week injection regimen in some patients [69].

Somatuline ${ }^{\circledR}$ LA (Beaufour Ipsen, Paris, France), the slow-release lanreotide, is also a microencapsulated compound, and is given by depot injection every 10 to 14 days [70]. A new form of lanreotide, a deep s.c. administered gel preparation (Somatuline ${ }^{\circledR}$ Autogel ${ }^{\circledR}$ ) has been introduced in clinical studies and can be injected monthly [71]. Somatuline LA and Somatuline Autogel are approved for use in some European countries.
Most acromegaly patients treated with analogs of somatostatin show a significant decrease in serum GH and IGF-I levels. In a review of published outcomes [72], Freda reported that serum levels of IGF-I were lowered to the normal range in an average of $66 \%$ of patients treated with octreotide LAR (in 6 combined studies), and in an average of $48 \%$ of patients treated with lanreotide SR (in 13 studies). GH was suppressed in an average of $56 \%$ of patients treated with octreotide LAR (compiling data from 7 studies), and in an average of $49 \%$ of patients treated with lanreotide SR (in 12 studies). Across the various studies, wide variability in outcomes is reported, probably as an effect of differences in length of follow-up, drug doses, and criteria employed in the assessment of GH status. As observed by Freda, most studies examining the efficacy of octreotide LAR analyzed response to treatment in patients preselected for response to s.c. octreotide, and therefore the data on LAR therapy may not accurately reflect response rates in a de novo population.

Somatostatin analog treatment is associated with some degree of reduction in tumor volume in at least $30 \%$ of patients [72]. Subcutaneous octreotide has been reported to decrease macroadenoma volume by about $75 \%$ in one case report [73] and by 20 to 54 percent when given pre-operatively in a small group of patients [74]. Indeed, most studies report a decrease in tumor volume of between 20 and 50 percent as assessed in the review by Freda[72], in which data from fifteen studies of longacting preparations and s.c. octreotide were gathered. The effect of octreotide on tumor size is reportedly due to a direct reduction in cell volume or number, as opposed to an anti-angiogenesis effect [75].

Preoperative somatostatin analog treatment is reported to improve the acromegaly patient's general condition for pituitary surgery, and should theoretically improve surgical remission rates by shrinking or softening the tumor, making more complete resection easier to achieve [64,76-78]. Yet it remains uncertain whether this is in fact the case, as studies addressing the question are contradictory. Two prospective, randomized studies involving a total of 62 patients could detect no benefit of preoperative s.c. octreotide on rates of postoperative normalization of GH or IGF-I, or duration of hospital stay after surgery $[79,80]$. On the other hand, a retrospective analysis of 22 patients treated pre-operatively with s.c. octreotide, and compared with 37 patients left untreated before surgery demonstrated improvements in ECG tracings, blood pressures, and glucose and lipid profiles, which were associated with shorter hospital stays postoperatively [81]. Most importantly, the surgical cure rate, as defined by normalized IGF-I, was nearly twice as high in the octreotide-pretreated group as in the controls (54.5\% vs. $29.7 \%, p<0.005)$. Improvements in the surgical cure rates in octreotide-pretreated patients were also reported by two other groups $[82,83]$, but these improved outcomes were mainly limited to intrasellar macroadenomas. Thus, the ultimate value of octreotide pretreatment is still not certain. 
The beneficial affects of somatostatin analogs on cardiovascular performance in patients with acromegaly have been examined in detail in two prospective studies. Subcutaneous octreotide increased left ventricular ejection fraction and exercise workload, and improved exercise duration while decreasing heart rate and blood pressure in 30 acromegalic patients investigated by Colao et al. over a period of one year [84]. In a similar study of 15 octreotide-naïve patients treated with octreotide LAR for 6 months, left ventricular mass index (LVMi), interventricular septum thickness, and LV posterior wall thickness were improved in all patients after 3 and 6 months of treatment [85]. Six of eleven patients with left ventricular hypertrophy at study entry normalized their LVMi while on treatment. These positive cardiovascular effects were generally seen to occur more slowly in older patients with longer disease duration [85].

Somatostatin analogs appeared to prolong the time necessary for normalization of GH secretory status after treatment with stereotactic radiosurgery, as reported by Landolt et al. in a retrospective analysis [86]. This study of 31 patients treated with gamma knife irradiation suggests that octreotide acts in a radioprotective manner on GH-secreting adenomas and is thus counterproductive when given concurrenty with radiotherapy. Nine patients treated with s.c. or LAR octreotide at the time of radiation application reached normal IGF-I or GH only after a significantly longer interval, as compared with those patients not treated with anti-secretory medications at the time of irradiation. Randomized, prospective studies will be necessary to support or refute these findings.

Multiple side effects, most of which are related to the presence of somatostatin receptors in the gastrointestinal tract, may accompany the use of somatostatin analogs. These side effects are mostly mild to moderate and are usually transient, although they can be more serious. In a report of 103 patients treated with s.c. octreotide, Newman et al. [87] reported diarrhea, nausea, abdominal discomfort, and loosened stools, though these typically resolved within 3 months of treatment. Though no patient developed cholecystitis, one of every five patients with normal ultrasound examinations at baseline developed gallbladder sludge, and another one fourth developed asymptomatic cholelithiasis [87].

Carbohydrate metabolism may be altered by somatostatin analog therapy by virtue of the suppression of insulin and glucagon secretion, though these concerns do not appear to be of major consequence during surveillance lasting 3 to 4 years. In a study of 36 patients followed for up to 24 months while on octreotide LAR therapy [88], after 3 months, mean fasting serum insulin levels had decreased from $17.7 \mathrm{mU} / \mathrm{L}$ to $10.5 \mathrm{mU} / \mathrm{L}$, while fasting glucose levels increased slightly from $95 \mathrm{mg} / \mathrm{dL}$ to $106 \mathrm{mg} / \mathrm{dL}$. No difference, however, was found in serum fasting glucose concentrations after 1224 months of treatment. In another study of 22 patients followed for an average of 41 months, glucose tolerance improved in 5 patients; new glucose intolerance developed in 4 patients while GH levels were improving or unchanged [89]. Whether longer-term treatment with somatostatin analogs independently increases the risk for development of type 2 diabetes mellitus is not known. The yearly follow-up of glucose tolerance and of fasting glucose levels in patients being treated with octreotide or lanreotide is a sensible precaution.

The efficacy of somatostatin analogs in subduing GH hypersecretion has renewed attention on the role of medical therapy for the primary treatment of acromegaly, and two multicenter studies have been encouraging in this regard. Bevan et al. examined the effects of octreotide as primary treatment in 27 patients with acromegaly, of whom 20 had macroadenomas [90]. Patients were initially given s.c. octreotide $100-200 \mathrm{mcg}$ t.i.d. for 24 weeks, during which time serum IGF-I was normalized in $33 \%$ of patients, while nadir GH was reduced to under $2 \mathrm{ng} / \mathrm{mL}$ in 38\%. During an additional 24 weeks in which 15 patients were continued on octreotide LAR 20-30 mg i.m. every 4 weeks, IGF-I reverted to normal in $53 \%$, while nadir GH fell to less than $2 \mathrm{ng} / \mathrm{mL}$ in $79 \%$ of patients. Impressively, tumor size was reduced by more than $10 \%$ in all patients save one. Median tumor volume shrinkage in macroadenomas was $43 \%$ during s.c. octreotide, while microadenomas were reduced by a median of $49 \%$. A further overall median tumor volume decrease of $24 \%$ was seen during octreotide LAR therapy, and tumor shrinkage continued throughout the year-long study such that $73 \%$ of patients showed tumor volume reduction greater than $30 \%$. The authors noted that patients with pre-treatment GH levels less than $20 \mathrm{ng} / \mathrm{mL}$ stood the best chance of having normalization of GH/IGF-I levels together with substantial tumor volume reduction [90]. Newman et al. published a 6-month study of 26 previously untreated acromegaly patients, in whom s.c. octreotide was as effective in reducing GH and IGF-I as it was in 81 patients with persistent GH-hypersecretion following surgery and/or radiotherapy, though tumor shrinkage was observed in only 6 of 13 patients [91]. Other studies also attest to the utility of SST analogs in the primary treatment of acromegaly [83,84,92]. The cost of life-long treatment with these drugs weighs against their use as primary treatment, especially in the case of pituitary microadenomas where the probability of surgical cure is high, or even for macroadenomas confined to the sella which might be resected in toto. It appears that use of these agents as primary treatment, in lieu of surgery, is best considered when the possibility of surgical cure is low, as in patients with large, invasive macroadenomas or where surgery is contraindicated, or declined by the patient. However, patients with large tumors and serum GH levels of greater than $20-30 \mathrm{ng} / \mathrm{mL}$ prior to treatment are also unlikely to have a satisfactory response to somatostatin analogs as primary therapy. They, as well as those patients harboring large, aggressive, grossly invasive tumors that are unlikely to respond well to either treatment alone, are probably best served by surgical 
debulking at the hands of an experienced pituitary surgeon, followed by somatostatin analog therapy.

\section{Growth Hormone Receptor Antagonist Therapy}

Pegvisomant (Somavert ${ }^{\circledR}$, Pharmacia Corp., Peapack, New Jersey, USA), the first growth hormone receptor (GHR) antagonist, is expected to join the medical armamentarium of acromegaly treatment in 2003. By nature of the prevention of post-GH receptor signal transduction, pegvisomant represents a novel treatment modality and a new paradigm in the management of acromegaly; and is exemplary of the clinical application of genetic engineering. It conveys an advantage over anti-secretory drugs in being independent of tumor expression of SST or $\mathrm{D}_{2}$ receptors, and has been extraordinarily efficacious in normalizing serum IGF-I in two published studies. Blockade of the physiological action of $\mathrm{GH}$ at the cellular level occurs through the use of a modified GH molecule, a competitive antagonist of the GH-receptor which prevents GH-induced transcription of IGF-I genes.

The elucidation of the mechanism of interaction between GH and its receptor [93,94] preceded the purposeful design of the GHR antagonist [95,96]. Human growth hormone is a polypeptide chain of 191 amino acid length, with a tertiary structure of four alpha-helices in a bundled core. The GH molecule is bivalent, capable of interfacing sequentially with two GHRs at separate binding domains (sites I and II) [97], thereby inducing the dimerization of two GHR molecules at the target cell surface. Fifty to sixty percent of GH in serum is unbound by the GH-binding protein [98], and is free to bind the GHR. When GH contacts a single GHR molecule on the cell surface, the two form the GH-GHR complex via binding at site I. The GH-GHR complex is then joined by a second cell-surface GHR molecule [92,99,100]; the dimerization of two GHR molecules is the final necessary event for activation of signal transduction, with transcription of the genes coding for IGF-I following sequentially.

Pegvisomant is a genetically modified GH molecule with nine amino acid substitutions within binding sites I and II that result in two important differences from the action of native GH [101,102]. Amino acid substitutions in binding site I afford pegvisomant a 30-fold increased affinity over native GH [93,101]. After the joining of the GHR antagonist and the first GH receptor, GHR dimerization is prevented by the presence of a long sidechain amino acid substituted within site II of pegvisomant [102]. The addition of 4 or 5 polyethylene glycol moieties enhances the competitive advantage of pegvisomant over native $\mathrm{GH}$ by prolonging its serum half-life to roughly 72 hours, and also lowers immunogenic potential $[103,104]$.

Outcomes of a randomized, double blind, placebocontrolled multicenter trial of pegvisomant in 112 acromegaly patients were first published in 2000 [105]. Pegvisomant resulted in normalization of IGF-I in 54, 81 and 89 percent of patients given daily doses of 10,15 and $20 \mathrm{mg}$, respectively; demonstrating a dose-dependent effect on IGF-I reduction. Significant improvement in symptom complexes was achieved in patients treated with pegvisomant $15 \mathrm{mg}$ and $20 \mathrm{mg}$ daily. Van der Lely et al. reported normalization of IGF-I in $97 \%$ of patients treated with pegvisomant in doses up to $40 \mathrm{mg}$ daily in a subsequent analysis of long-term efficacy and safety of 160 patients observed over a mean follow-up of 14 months [106]. The normalization of IGF-I was associated with a fall in mean fasting serum insulin concentrations and in mean fasting glucose at 6 months of follow-up, indicating a positive affect on the insulin resistance and hyperinsulinemia of acromegaly [106].

Pegvisomant was well tolerated in both studies, though new serologic evidence of asymptomatic hepatocellular injury without hepatobiliary involvement was seen in a total of three patients shortly after the initiation of pegvisomant [105,106]. Aminotransaminase levels returned to normal in all three patients when the drug was withdrawn. Antibodies to GH or to pegvisomant were detected in up to one fifth of patients, though no patient developed tachyphylaxis. Serum GH concentrations increased during pegvisomant therapy, presumably a result of the loss of IGF-I negative feedback, which raises the possibility of tumor enlargement due to GHR antagonist treatment. In both studies, magnetic resonance imaging of the pituitary before and after pegvisomant treatment was carried out. Two patients with aggressive tumors showed tumor enlargement during therapy, though one may have enlarged during a 5-month period on octreotide alone. A later sub-analysis of MRI data from 131 patients reported by van der Lely et al. accounted for tumor volume before and after pegvisomant and stratified tumor response according to prior treatment scheme [107]. After a mean follow-up of one year, mean tumor volume decreased by $0.04 \pm 0.06 \mathrm{~cm}^{3}$ from $2.38 \mathrm{~cm}^{3}$ (range, $0.11-15.18 \mathrm{~cm}^{3}$ ) at baseline. No significant change in tumor volume in relation to baseline or other treatment groups could be demonstrated.

Pegvisomant's dependence on the disruption of interaction between GH and peripheral tissue as a means of disease control provides a fundamental distinction to the GH-suppressive medications. GH receptor antagonist therapy will be a welcome addition to the treatment options for the control of persistently elevated serum IGF-I in acromegaly patients not adequately treated by surgery, radiation, and/or anti-secretory therapy. Pegvisomant promises a very high rate of normalization of IGF-I in patients with acromegaly. The liver enzyme elevation seen in a small number of patients indicates the need for vigilance in the setting of known liver disease, and monitoring of liver enzymes should be undertaken in all patients treated, though the duration of surveillance necessary remains to be determined. Monitoring for potential tumor enlargement with periodic MRI scans is also warranted. The dose of pegvisomant should be titrated to target serum IGF-I levels within normal age- and sex-controlled ranges to achieve 
adequate disease control. Pegvisomant's predictable effect on IGF-I may allow for future targeting of a precise quadrant within the normal IGF-I range to achieve optimal disease control while avoiding symptoms of GH deficiency. Studies are also needed to determine the appropriate use of pegvisomant in the primary treatment of acromegaly, in children with gigantism, in pregnant women and in potential combination with somatostatin analogues and/or dopamine agonists.

\section{Estrogen Therapy}

Early data by Clemmons et al. have shown that estrogen lowers serum IGF-I in patients with acromegaly and effects beneficial clinical and biochemical responses [108], due to the effect of estrogen on hepatic and, presumably, extrahepatic IGF-I biosynthesis [109]. This approach is, for obvious reasons, impractical in men, although we successfully employed it in several women with mild residual disease. The selective estrogen receptor modulators tamoxifen and raloxifene have recently been shown to have a similar effect $[110,111]$, and this approach may prove to be useful in selected groups of patients.

\section{Summary}

Most patients with acromegaly present with tumors that cannot be completely resected, and require further treatment for disease management following pituitary microsurgery. Radiotherapy requires several years to control GH-hypersecretion, and the discouraging adverse effect of hypopituitarism occurs in about half of patients by the time GH secretion is subdued. Meanwhile, the range of products available for the medical treatment of acromegaly has developed into an adaptable assortment; and new additions on the horizon promise to broaden the array of treatment options.

Growth hormone suppression with cabergoline is well tolerated and remains a worthwhile strategy, particularly in patients with concurrent hyperprolactinemia. Still, not more than half of such patients achieve a normalized IGF-I on cabergoline, and the success rate with GH-excess alone is even less. The long-acting somatostatin analogs lanreotide SR and octreotide LAR set the standard for the medical treatment of acromegaly in the pre-GHR antagonist era as a result of their superior efficacy in comparison with the dopamine agonists. A majority of patients may have significant tumor shrinkage with SST analogs, though this effect cannot always be counted on, and at least one third of patients do not have a satisfactory biochemical response.

Pharmacologic blockade of the GH receptor is about to emerge as a highly effective secondary treatment of acromegaly in the majority of patients requiring aggressive postoperative therapy. Pegvisomant renders inconsequential the GH hypersecretion of residual tumor cells refractory to GH-suppressive therapy, and as such has highlighted the recognition of serum IGF-I concentration as the truest marker of disease status in acromegaly. The normalization of circulating IGF-I, as the foremost biochemical goal of the treatment of acromegaly, is about to be brought within reach for essentially all patients with this debilitating disease.

\section{References}

1. Herman V, Fagin J, Gonsky R, Kovacs K, Melmed S. Clonal origin of pituitary adenomas. J Clin Endocrinol Metab 1990;71:1427-1433.

2. Biller BMK, Swearingen B, Zervas NT, Klibanski A. Profiles of the endocrine clinic: A decade of the Massachusetts general hospital neuroendocrine clinical center. J Clin Endocrinol Metab 1997;82:1668-1674.

3. Ilan S, Melmed S. Management of pituitary tumors. Ann Intern Med 1998;129:472-483.

4. Molitch ME. Clinical manifestations of acromegaly. Endocrinol Metab Clin North Am 1992;21:597-614.

5. Rajasoorya C, Holdaway IM, Wrightson P, Scott DJ, Ibbertson HK. Determinants of clinical outcome and survival in acromegaly. Clin Endocrinol (Oxf) 1994;41;95-102.

6. Orme SM, McNally RJQ, Cartwright RA, Belchetz PE. Mortality and cancer incidence in acromegaly: A retrospective cohort study. J Clin Endocrinol Metab 1998;83:2730-2734.

7. Kreutzer J, Vance ML, Lopes MBS, Laws ER. Surgical management of GH-secreting pituitary adenomas: An outcome study using modern remission criteria. J Clin Endocrinol Metab 2001;86:4072-4077.

8. Freda PU, Wardlaw SL, Post KD. Long-term endocrinologic follow-up after transsphenoidal surgery for acromegaly. $\mathrm{J} \mathrm{Neu}$ rosurg 1998;89:353-358.

9. Swearingen B, Barker II FG, Katznelson L, Biller BMK, Grinspoon S, Klibanski A, et al. Long-term mortality after transsphenoidal surgery and adjunctive therapy for acromegaly. J Clin Endocrinol Metab 1998;83:3419-3426.

10. Sheaves R, Jenkins P, Blackburn P, Huneidi AH, Afshar F, Medback S, et al. Outcome of transsphenoidal surgery for acromegaly using strict criteria for surgical cure. Clin Endocrinol 1996;45:407-413.

11. Snyder PH, Fowble BF, Schatz NJ, Savino PH, Gennarelli TA. Hypopituitarism following radiation therapy of pituitary adenomas. Am J Med 1986;81:457-462.

12. Eastman RC, Gorden P, Glatstein E, Roth J. Radiation therapy of acromegaly. Endocrinol Metab Clin North Am 1992;21:693712.

13. Powell JS, Wardlaw SL, Post KD, Freda PU. Outcome of radiotherapy for acromegaly using normalization of insulinlike growth factor I to define cure. J Clin Endocrinol Metab 2000;85:2068-2071.

14. Barkan AL, Halasz I, Dornfeld KJ, Jaffe CA, DeMott-Friberg R, Chandler WF, et al. Pituitary irradiation is ineffective in normalizing plasma insulin-like growth factor I in patients with acromegaly. J Clin Endocrinol Metab 1997;82:3187-3191.

15. Biermasz NR, van Dulken H, Roelfsma F. Long-term followup results of postoperative radiotherapy in 36 patients with acromegaly. J Clin Endocrinol Metab 2000;85:2476-2482.

16. Barrande G, Pittino-Lungo M, Coste J, Ponvert D, Bertagna $\mathrm{X}$, Luton JP, Bertherat J. Hormonal and metabolic effects of radiotherapy in acromegaly: Long-term results in 128 patients followed in a single center. J Clin Endocrinol Metab 2000;85:3779-3785. 
17. Jackson IM, Noren G. Role of gamma knife radiosurgery in acromegaly. Pituitary 1999;2:71-77.

18. Kliman B, Kjellberg RM, Swisher B, Butler W. Proton beam therapy in acromegaly: A 20-year experience. In Black PMcL, Zervas NT, Ridgway EC \& Martin JB, eds. Secretory Tumours of the Pituitary Gland. Progress in Endocrine Research and Therapy. Raven Press, 1984;1:191-211.

19. Voges J, Sturm V, Deuss U, Traud C, Treuer H, Schlegel W, et al. LINAC-radiosurgery (LINAC-RS) in pituitary adenomas: Preliminary results. Acta Neurochirurg-Supple 1996;65:41-43.

20. Chiodini PG, Cozzi R, Dallabonanza D, Oppizzi G, Verde G, Petroncini M, et al. Medical treatment of acromegaly with SMS 201-995, a somatostatin analog: A comparison with bromocriptine. J Clin Endocrinol Metab 1987;64:447-453.

21. Bates AS, Van't Hott W, Jones JM, Clayton RN. Does treatment of acromegaly affect life expectancy? Metab Clin Exper 1995;44:1-5.

22. Abosch A, Tyrrell JB, Lamborn KR, Hannegan LT, Applebury CB, Wilson CB. Transsphenoidal microsurgery for growthhormone secreting pituitary adenomas: Initial outcome and long-term results. J Clin Endocrinol Metab 1998;83:3411-3418.

23. Giustina A, Barkan A, Casaneuva FF, Cavagnini F, Frohman L, Ho K, et al. Criteria for cure of acromegaly: A consensus statement. J Clin Endocrinol Metab 2000;85:526-529.

24. Trainer P. Editorial: Acromegaly-Consensus, what consensus? J Clin Endocrinol Metab 2002;87:3534-3536.

25. Frohman LA. Acromegaly: What constitutes optimal therapy? J Clin Endocrinol Metab 1996;81:443-445.

26. Freda PU, Post KD, Powell JS, Wardlaw SL. Evaluation of disease status with sensitive measures of growth hormone secretion in 60 postoperative patients with acromegaly. $J$ Clin Endocrinol Metab 1998;83:3808-3816.

27. Costa ACF, Rossi A, Martinelli CE, Jr., Machado HR, Moreira AC. Assessment of disease activity in treated acromegalic patients using a sensitive GH assay: Should we achieve strict normal GH levels for a biochemical cure? J Clin Endocrinol Metab 2002;87:3142-3147.

28. Melmed S, Ho K, Klibanski A, Reichlin S, Thorner M. Recent advances in pathogenesis, diagnosis, and management of acromegaly. J Clin Endocrinol Metab 1995;80: 3395-3402.

29. Melmed S, Jackson I, Kleinberg D, Klibanski A. Current treatment guidelines for acromegaly. J Clin Endocrinol Metab 1998;83:2646-2652.

30. Barkan AL, Beitins IZ, Kelch RP. Plasma insulin-like growth factor-I/somatomedin-C in acromegaly: Correlation with the degree of growth hormone hypersecretion. J Clin Endocrinol Metab 1988;67:69-73.

31. Ho KKY, Weissberger AJ. Characterization of 24-hour growth hormone secretion in acromegaly: Implications for diagnosis and therapy. Clin Endocrinol (Oxf) 1994;41:75-83.

32. Dimaraki EV, Jaffe CA, DeMott-Friberg R, Chandler WF, Barkan AL. Acromegaly with apparently normal GH secretion: Implications for diagnosis and follow-up. $J$ Clin Endocrinol Metab 2002;87:3534-3536.

33. Katznelson L, Klibanski A. Prolactin and its disorders. In: Becker KL, ed. Principles and Practice of Endocrinology and Metabolism. Philadelphia: Lippincott Williams \& Wilkins, 2001:145-153.

34. Kovacs K, Horvath E. Pathology of pituitary tumors. Endocrinol Metab Clin North Am 1987;16:529-551.

35. Tabarin A, Carrie F, Ronci N, Charrin G, Fournier MC, Beckers A, et al. Dopamine D2 receptor gene expression in growth hormone-producing pituitary adenomas. In: Proc.4th Int'l
Pituitary Congress, San Diego, CA, June 16-18, 1996: abstract H5.

36. Liuzzi A, Chiodini PG, Botalla L, Cremascoli G, MÜller EE, Silvestrini F. Decreased plasma growth hormone (GH) levels in acromegalics following CB 154 (2-Br-alpha-ergocrytpine) administration. J Clin Endocrinol Metab 1974;38:910-914.

37. Lamberts SW, Klijn JG, van Vroonhaven CC, Stefanko SZ. Different responses of growth hormone secretion to guanfacine, bromocriptine, and thyrotropin-releasing hormone in acromegalic patients with pure growth hormone (GH)-containing and mixed GH/prolactin-containing pituitary adenomas. J Clin Endocrinol Metab 1985;60:1148-1153.

38. Jaffe CA, Barkan AL. Treatment of acromegaly with dopamine agonists. Endocrinol Metab Clinics N Am 1994;21: 713-735.

39. Summers VK, Hipkin LJ, Diver MJ, Davis JC. Treatment of acromegaly with bromocriptine. J Clin Endocrinol Metab 1975;40:904-908.

40. Kleinberg DL, Boyd III AE, Wardlaw S, Frantz AG, George A, Bryan N, et al. Pergolide for the treatment of pituitary tumors secreting prolactin or growth hormone. $N$ Eng J Med 1983;309:704-709.

41. Kendall-Taylor P, Upstill-Goddard G, Cook D. Longterm pergolide treatment of acromegaly. Clin Endocrinol 1983;19:711719

42. Rains CP, Brayson HM, Fitton A. Cabergoline: A review of its pharmacological properties and therapeutic potential in the treatment of hyperprolactinemia and inhibition of lactation. Drugs 1995;49:255-279.

43. Abs R, Verhelst J, Dominique M, van Acker K, Nobels F, Coolens J-L, et al. Cabergoline in the treatment of acromegaly: A study in 64 patients. J Clin Endocrinol Metab 1998;83: 374-378.

44. Cozzi R, Attanasio R, Barausse M, Dallabonanza D, Orlandi $\mathrm{P}$, Da Re N, et al. Cabergoline in acromegaly: A renewed role for dopamine agonist treatment? Europ J Endocrinol 1998;139:516-521.

45. Reichlin S. Somatostatin. N Eng J Med 1983;309:1495-1501.

46. Reichlin S. Somatostatin (second of two parts). N Eng J Med 1983;309:1556-1563.

47. Patel Y. Somatostatin. In: Becker KL, ed. Principles and Practice of Endocrinology and Metabolism. Philadelphia: Lippincott Williams \& Wilkins, 2001:1564-1575.

48. Krulich L, Dhariwal APS, McCAnn SM. Stimulatory and inhibitory effects of purified hypothalamic extracts on growth hormone release from rat pituitary in vitro. Endocrinology 1968;83:783-790.

49. Pradayrol L, Jornvall H, Mutt V, Ribet A. N-terminally extended somatostatin: The primary structure of somatostatin-28. FEBS Letters 1980;109:55-88.

50. Yamada Y, Reisine T, Law SF, Ihara Y, Kubota A, Kagimoto $\mathrm{S}$, et al. Somatostatin receptors, an expanding gene family: Cloning and functional characterization of human sstR3, a protein coupled to adenylyl cyclase. Mol Endocrinol 1992;6:21362142.

51. O'Carroll AM, Lolait SJ, Konig M, Mahan LC. Molecular cloning and expression of a pituitary somatostatin receptor with preferential affinity for somatostatin-28. Mol Pharmacol 1992;42:939-946.

52. Yamada Y, Post SR, Wang K, Tager HS, Bell GI, Seino S. Cloning and functional characterization of a family of human and mouse somatostatin receptors expressed in brain, gastrointestinal tract, and kidney. Proc Natl Acad Sci USA 1992;89:251255 . 
53. Panetta R, Patel YC. Expression of mRNA for all five human somatostatin receptors (hSSTR1-5) in pituitary tumors. Life Sci 1995;56:333-342.

54. Jaquet P, Saveanu A, Gunz G, Fina F, Zamora AJ, Grino M, et al. Human somatostatin receptor subtypes in acromegaly: Distinct patterns of messenger ribonucleic acid expression and hormone suppression identify different tumoral phenotypes. J Clin Endocrinol Metab 2000;85:781-792.

55. Reubi JC, Landolt AM. The growth hormone responses to octreotide in acromegaly correlate with adenoma somatostatin receptor status. J Clin Endocrinol Metab 1989;68:844-850.

56. Ballar E, Persani L, Lania AG, Filopanti M, Giammona E, Corbetta S, et al. Mutation of somatostatin receptor type 5 in an acromegalic patient resistant to somatostatin analog treatment. J Clin Endocrinol Metab 2001;86:3809-3814.

57. Lamberts SWJ, van Der Lely A-J, de Herder WW, Hofland LJ. Octreotide. N Eng J Med 1996;334:246-254.

58. Bauer W, Briner U, Doepfner W, Haller R, Huguenin R, Marbach P, et al. SMS 201-995: A very potent and selective octapeptide analogue of somatostatin with prolonged action. Life Sci 1982;31:1133-1140.

59. Ho KY, Weissberger AJ, Marbach P, Lazarus L. Therapeutic efficacy of the somatostatin analog SMS 201-995 (octreotide) in acromegaly. Effects of dose and frequency and long-term safety. Ann Intern Med 1990;112:173-181.

60. Lamberts SW, Uitterlinden P, Verschoor L, van Dongen KJ, del Pozo E. Long-term treatment of acromegaly with the somatostatin analogue SMS 201-995. N Engl J Med 1985;313:15761580 .

61. Lamberts SW, Uitterlinden P, del Pozo E. SMS 201-995 induces a continuous decline in circulating growth hormone and somatomedin-C levels during therapy of acromegalic patients for over two years. J Clin Endocrinol Metab 1987;65:703-710.

62. Comi RJ, Gorden P. The response of serum growth hormone levels to the long-acting somatostatin analog 201-995 in acromegaly. J Clin Endocrinol Metab 1987;64:37-42.

63. Barkan AL, Kelch RP, Hopwood NJ, Beitins IZ. Treatment of acromegaly with the long-acting somatostatin analog SMS 201995. J Clin Endocrinol Metab 1988;66:16-23.

64. Vance ML, Harris AG. Long-term treatment of 189 acromegalic patients with the somatostatin analog octreotide. Results of the international multicenter acromegaly study group. Arch Int Med 1991;151:1573-1578.

65. Lombardi G, Colao A, Ferone D, Sarnacchiaro F, Marzullo P, Di Sarno A, et al. CV 205-502 treatment in therapy-resistant acromegalic patients. Eur J Endocrinol 1995;132:559-564.

66. Colao A, Ferone D, Lastoria S, Marzullo P, Cerbone G, Di Sarno A, et al. Prediction of efficacy of octreotide therapy in patients with acromegaly. J Clin Endocrinol Metab 1996;81:2356-2362.

67. Grass P, Marbach P, Bruns C, Lancranjan I. Sandostatin LAR (microencapsulated octreotide acetate) in acromegaly: Pharmacokinetic and pharmacodynamic relationships. Metabolism 1996;45:27-30.

68. Lancranjan I, Bruns C, Grass P, Jaquet P, Jervell J, KendallTaylor P, et al. Sandostatin LAR: A promising therapeutic tool in the management of acromegalic patients. Metabolism 1996;45:67-71.

69. Biermasz NR, van den Oever NC, Pereira Arias AM, Smit JW, Romijn JA, Roelfsema F. A six weekly injection scheme of Sandostatin LAR suppresses GH secretion in acromegalics as effectively as a four weekly scheme. The Endocrine Society's 84th Annual Meeting. San Francisco, CA, June 19-22, 2002.

70. Heron I, Thomas F, Dero M, Gancel A, Ruiz JM, Schatz B, et al. Pharmacokinetics and efficacy of a long-acting formulation of the new somatostatin analog BIM 23014 in patients with acromegaly. J Clin Endocrinol Metab 1993;76:721-727.

71. Caron P. Somatuline ${ }^{\circledR}$ Autoge ${ }^{\circledR}$, a new formulation of lanreotide for the treatment of acromegalic patients. Annales d' Endocrinologie 2002;63:2S19-24.

72. Freda PU. Somatostatin analogs in acromegaly. J Clin Endocrinol Metab 2002;87:3013-3018.

73. Ducasse MC, Tauber JP, Tourre A, Bonafe A, Babin T, Tauber MT, et al. Shrinking of a growth hormone-producing pituitary tumor by continuous infusion of the somatostatin analog SMS 201-995. J Clin Endocrinol Metab 1987;65:1042-1046.

74. Barkan AL, Lloyd RV, Chandler WF, Hatfield MK, Gebarski SS, Kelch RP, et al. Preoperative treatment of acromegaly with long-acting somatostatin analog SMS 201-995: Shrinking of invasive pituitary macroadenomas and improved surgical remission rate. J Clin Endocrinol Metab 1988;67:1040-1048.

75. Atkin AL, Lowry M, Hill CR, Turnbull LW. Octreotide shrinks the cellular rather than the vascular compartment in acromegalic tumours in vivo. The Endocrine Society's 84th Annual Meeting. San Francisco, CA, June 19-22, 2002.

76. Ezzat S, Snyder PJ, Young WF, Boyajy LD, Newman C, Klibanski A, et al. Octreotide treatment of acromegaly. A randomized, multicenter study. Ann Intern Med 1992;117:711-718.

77. Newman CB, Melmed S, Snyder PJ, Young WF, Boyajy LD, Levy $\mathrm{R}$, et al. Safety and efficacy of long term octreotide therapy of acromegaly: Results of a multicenter trial in 103 patientsa clinical research center study. J Clin Endocrinol Metab 1995;80:2768-2775.

78. Newman CB, Melmed S, George A, Torigan D, Duhaney M, Snyder P, et al. Octreotide as primary therapy for acromegaly. J Clin Endocrinol Metab 1998;83:3034-3040.

79. Biermasz NR, van Dulken H, Roelfsema F. Direct postoperative and follow-up results of transsphenoidal surgery in 19 acromegalic patients pretreated with octreotide compared to those in untreated matched controls. J Clin Endocrinol Metab 1999;84:3551-3555.

80. Kristof RA, Stoffel-Wagner B, Klingmüller D, Schramm J. Does octreotide treatment improve the surgical results of macroadenomas in acromegaly? A randomized study. Acta Neurochir 1999;141:399-405.

81. Colao A, Ferone D, Cappabianca P, del Basso De Caro ML, Marzullo P, Monticelli A, et al. Effect of octreotide pretreatment on surgical outcome in acromegaly. J Clin Endocrinol Metab 1997;82:3308-3314.

82. Stevenaert A, Beckers A. Presurgical octreotide: Treatment in acromegaly. Metab: Clin \& Exp 1996;45(8 Suppl 1):72-74.

83. Abe T, Ludecke D. Effects of preoperative octreotide treatment on different subtypes of $90 \mathrm{GH}$-secreting pituitary adenomas and outcome in one surgical centre. Eur J Endocrinol 2001;145:137-145.

84. Colao A, Cuocolo A, Marzullo P, Nicolai E, Ferone D, Florimonte L, et al. Effects of 1-year treatment with octreotide on cardiac performance in patients with acromegaly. J Clin Endocrinol Metab 1999;84:17-23.

85. Colao A, Marzullo P, Ferone D, Spinelli L, Cuocolo A, Bonaduce D, et al. Cardiovascular effects of depot long-acting somatostatin analog Sandostatin LAR in acromegaly. J Clin Endocrinol Metab 2000;85:3132-3140.

86. Landolt AM, Haller D, Lomax N, Scheib S, Schubiger O, Siegfried J, et al. Octreotide may act as a radioprotective agent in acromegaly. J Clin Endocrinol Metab 2000;85:1287-1289.

87. Newman CB, Melmed S, Snyder PJ, Young WF, Boyajy LD, Levy R, et al. Safety and efficacy of long term octreotide therapy of acromegaly: Results of a multicenter trial in 103 
patients - a clinical research center study. J Clin Endocrinol Metab 1995;80:2768-2775.

88. Colao A, Ferone D, Marzullo P, Cappabianca P, Cirillo S, Boerlin V, et al. Long-term effects of depot long-acting somatostatin analog octreotide on hormone levels and tumor mass in acromegaly. J Clin Endocrinol Metab 2001;86:2779-2786.

89. Ayuk J, Stewart SE, Stewart PM, Sheppard MC. Long-term safety and efficacy of depot long-acting somatostatin analogs for the treatment of acromegaly. J Clin Endocrinol Metab 2002;87:4142-4146.

90. Bevan JS, Atkin SL, Atkinson AB, Bouloux P-M, Hanna F, et al. Primary medical therapy for acromegaly: An open, prospective, multicenter study of the effects of subcutaneous and intramuscular slow-release octreotide on growth hormone, insulinlike growth factor-I, and tumor size. J Clin Endocrinol Metab 2002;87:4554-4563.

91. Newman CB, Melmed S, George A, Torigan D, Duhaney M, Snyder P, et al. Octreotide as primary therapy for acromegaly. J Clin Endocrinol Metab 1998;83:3034-3040.

92. Amato G, Mazziotti G, Rotondi M, Iorio S, Doga M, Sorvillo F, et al. Long-term effects of lanreotide SR and octreotide LAR on tumour shrinkage and GH hypersecretion in patients with previously untreated acromegaly. Clin Endocrinol (Oxf) 2002;56:65-71.

93. Cunningham BC, Ultsch M, De Vos AM, Mulkerrin MG, Clauser KR, Wells JA. Dimerization of the extracellular domain of the human growth hormone receptor by a single hormone molecule. Science 1991;254:821-825.

94. Fuh G, Mulkerrin MG, Bass S, et al. The human growth hormone receptor. Secretion from $E$. Coli and disulfide bonding pattern of the extracellular binding domain. $J$ Biol Chem 1990;265:3111-3115.

95. Fuh G, Cunningham BC, Fukunaga R, Goeddel DV, Wells JA. Rational design of potent antagonists to the human growth hormone receptor. Science 1992;256:1677-1680.

96. Kopchick JJ, Parkinson C, Stevens EC, Trainer PJ. Growth hormone receptor antagonists: Discovery, development, and use in patients with acromegaly. Endo Rev 2002;23: 623-646.

97. Chen WY, Chen NY, Yun J, et al. Amino acid residues in the third alpha-helix of growth hormone involved in growth promoting activity. Mol Endocrinol 1995;9:292-302.

98. Daughaday WH, Trivedi B, Andrews BA. The ontogeny of serum GH binding protein in man: A possible indicator of hepatic GH receptor development. J Clin Endocrinol Metab 1987;65:1072-1074.
99. Ultsch M, De Vos AM, Kossiakoff AA. Crystals of the complex between human growth hormone and the extracellular domain of its receptor. J Mol Biol 1991;222:865-868.

100. De Vos AM, Ultsch M, Kossiakoff AA. Human growth hormone and extracellular domain of its receptor: Crystal structure of the complex. Science 1992;255:306-312.

101. Parkinson C, Trainer PJ. Growth hormone receptor antagonists: Therapy for acromegaly. Baillère's Clin Endocrinol Metab 1999;13:419-430.

102. Cunningham BC, Henner DJ, Wells JA. Engineering human prolactin to bind to the human growth hormone receptor. Science 1990;247:1461-1465.

103. Cunningham BC, Lowman HB, Wells JA, Clark RG, Olson K, Fuh G. Human growth hormone variants. (1998) US Patent No. 5. 849:535.

104. Lowman HB, Wells JA. Affinity maturation of human growth hormone by monovalent phage display. $J$ Mol Biol 1993;234:564-578.

105. Trainer PJ, Drake WM, Katznelson L, Freda PU, HermanBonert V, van der Lely AJ, et al. Treatment of acromegaly with the growth hormone-receptor antagonist pegvisomant. $N$ Engl J Med 2000;342:1171-1177.

106. van der Lely AJ, Hutson KR, Trainer PJ, Besser GM, Barkan AL, Katznelson L, et al. Long-term treatment of acromegaly with pegvisomant, a growth hormone receptor antagonist. The Lancet 2001;358:1754-1759.

107. Besser M, Hutson K. Pegvisomant, a novel GH receptor antagonist, does not affect pituitary tumor volume in patients with acromegaly regardless of prior therapy. The Endocrine Society's 84th Annual Meeting. San Francisco, CA, June 19-22, 2002.

108. Clemmons DR, Underwood LE, Ridgway EC, Kliman B, Kjellberg RN, Van Wyk JJ. Estradiol treatment of acromegaly. Reduction of immunoreactive somatomedin-C and improvements in metabolic status. Am J Med 1980;69:571-575.

109. Borski RJ, Tsai W, DeMott-Friberg R, Barkan AL. Regulation of somatic growth and the somatotropic axis by gonadal steroids: Primary effect on insulin-like growth factor I gene expression and secretion. Endocrinology 1996;137:3253-3259.

110. Dimaraki EV, Symons KV, Barkan AL. Is raloxifene useful in the treatment of acromegaly? The Endocrine Society's 84th Annual Meeting. San Francisco, CA, June 19-22, 2002.

111. Attanasio R, Barausse M, Dallabonanza D, Cozzi R. IGF-I lowering effect of estrogens in acromegaly. The Endocrine Society's 84th Annual Meeting. San Francisco, CA, June 19-22, 2002. 